\section{GA90-16: A Nonsweet, Staple-type Sweetpotato Breeding Line}

\author{
S.J. Kays, W.J. McLaurin, and Y. Wang \\ The Department of Horticulture, Plant Sciences Building, The University of \\ Georgia, Athens, GA 30602-7273
}

P.D. Dukes, J. Thies, J.R. Bohac, and D.M. Jackson

U.S. Vegetable Laboratory, Agricultural Research Service, U.S. Department of Agriculture, Charleston, SC 29407

Additional index words. Ipomoea batatas, vegetable breeding, disease resistance, insect resistance, nutrition, white potato, flavor, flavor chemistry

GA90-16 is a sweetpotato breeding line that has been developed jointly by the Univ. of Georgia and the U.S. Dept. of Agriculture (USDA) U.S. Vegetable Laboratory in Charleston, S.C. Flavor is a primary determinant in consumer acceptance (Kays et al., 1999) and the major distinguishing traits for the line are exceptionally low endogenous sugar and maltose content, reduced aroma, and firm texture in the cooked product. The composite effect is a cooked product with a flavor (taste and aroma) similar to potato (Solanum tuberosum L.). GA90-16 grows well under hot, humid conditions, has good resistance to the elongate flea beetle (Systena elongata Fabricius), the striped flea beetle ( $S$. blanda Melsheimer), the southern root-knot nematode [Meloidogyne incognita (Kofoid and White) Chitwood], and fusarium wilt (stem rot), caused by Fusarium oxysporum f. sp. batatas (Wr.) Snyd. \& Hans, and a much lower flavor intensity, similar to other staple crops [e.g., cassava (Manihot esculenta Crantz), potato, and rice (Oryza sativa L.)]. GA90-16 has excellent potential for developing commercial cultivars with low flavor impact for use as a staple or for blending with conventional sweetpotatoes or other foods to broaden the flavor potential of processed sweetpotato products.

\section{Origin}

GA90-16 is an open-pollinated seedling selection from a polycross nursery in 1990 of which the female parent was 'HiDry'. The exact parentage of 'HiDry' is not known; however, it was a 4th generation openpollinated selection from MK-14 in mass selection population J. MK-14 was a selection from open-pollinated seeds of 'Minamiyutuka' from the Kyushu Agricultural Experiment Station, Japan (Hamilton et al., 1985).

Received 16 Dec. 1999. Accepted for publication 3 July 2000. We thank Betty Schroeder for her technical assistance and Jim Collins for characterizing the potential of the line for french fries. The cost of publishing this paper was defrayed in part by the payment of page charges. Under postal regulations, this paper therefore must be hereby marked advertisement solely to indicate this fact.

\section{Description}

Habit. Annual, prostrate, vining plant (similar to 'Jewel'). pointed, acute to acuminate; base truncate to weakly cordate; margins entire with occasional irregular angled teeth; veins green to purple with greater anthocyanin toward the base and on the abaxial side; blade intermediate to dark green (RHS 137-A) (Royal Horticultural Society, 1987) with anthocyanin largely restricted to veins; leaf length to width ratio typically around 1.03 but ranging from 1.12 to 0.85 ; leaf size intermediate and variable depending upon the age of the plant when formed and production conditions; substantial leaf shedding, especially late in the season.

Petioles. Green to purple; length varying with age of the plant and canopy density.

Vines. More or less circular in cross-section, reaching 1 to $1.5 \mathrm{~m}$ in length [comparable to 'Jewel' (Somda and Kays, 1990)]; generally green with little anthocyanin; young stems slightly pubescent, becoming glabrous with age; rudimentary adventitious root(s) at nodes; branching secondary and occasionally tertiary with branch position and frequency depending upon plant density and production conditions.

Storage roots. Obovate in shape, light tan exterior (RHS 164-D), with the fresh roots having a cream interior (RHS 158-B).

Growing period. 120 to $140 \mathrm{~d}$.

Flavor. In baking trials, the flesh color was white with a yellowish tint (RHS 4-D) with the roots displaying little fiber or discoloration. The internal optical properties of the tissue varies with individual baked roots from translucent to opaque, the latter predominating in microwaved roots. The flavor of the baked roots, when contrasted with traditional North American sweetpotato cultivars, was described by taste panels as "bland", "like an Irish potato," and having a much drier texture. The chemical composition of roots baked in aluminum foil for $70 \mathrm{~min}$ at $204{ }^{\circ} \mathrm{C}$ is compared in Table 1 with that of 'Jewel', an intensely flavored, orange-fleshed commercial U.S. cultivar. The sugar concentration, expressed as total sugars or relative sweet-
Leaves. Alternate, ovate, tip abruptly ness (sucrose equivalents), is markedly lower than that of the traditional cultivar Jewel. Sugars and organic acids are the primary contributors to the taste in the sweetpotato (Kays et al., 1999). Sugars that are present in the uncooked roots (principally sucrose, fructose, and glucose) and maltose, which is formed during baking, are responsible for the sweetness. GA90-16 has very low levels of endogenous sugars and extremely low activity of the amylase system, which accounts for the exceptionally low hydrolysis of starch to maltose during cooking.

Aroma compounds are also critical components of the overall flavor. Table 2 lists the important odor-active volatile compounds and their relative significance. GA90-16 and 'Jewel' have distinctly different aromas, the former having much lower concentrations of odor-active volatiles, in keeping with the reduced flavor ratings of sensory panels. In 'Jewel', the odor-active compounds 1,2,4-trimethyl benzene, 2-acetyl furan, benzaldehyde, 2-pentyl furan, phenyl acetaldehyde, 2-acetyl pyrrole, maltol, linalool, geraniol, methyl geranate, $\alpha$-copaene, and $\beta$-ionone possessed flavor dilution factors (FD) (Wang and Kays, 2000) >800. GA90-16, in contrast, typically had lower FD factors for these aroma compounds, with the exception of 2-acetyl furan and $\alpha$-copaene. The cooked white potato aroma of GA90-16 appears to come mainly from 2-acetyl furan and 2,4-decadienal, the latter being important in the aroma of baked white potatoes (Buttery et al., 1973). While the FD factor of 2-acetyl furan in GA90-16 was equal to that of 'Jewel', the substantially higher level of

Table 1. Sugar and nonvolatile organic acid composition of baked 'Jewel' and GA90-16 sweetpotatoes $^{\mathrm{z}}$.

\begin{tabular}{|c|c|c|}
\hline Component & $\frac{\text { Jewel }}{\left(\mathrm{g} \cdot \mathrm{kg}^{-1} \mathrm{DM}\right)}$ & $\frac{\mathrm{GA} 90-16}{\left(\mathrm{~g} \cdot \mathrm{kg}^{-1} \mathrm{DM}\right.}$ \\
\hline \multicolumn{3}{|c|}{ Sugars } \\
\hline Fructose & 69.5 & 20.5 \\
\hline Glucose & 85.4 & 32.8 \\
\hline Sucrose & 185.5 & 53.3 \\
\hline Maltose & 241.8 & 1.0 \\
\hline Galactose & 2.0 & 0.8 \\
\hline Inositol & 1.2 & 1.1 \\
\hline Total sugars & 585.4 & 109.5 \\
\hline Total reducing sugars ${ }^{x}$ & 396.6 & 54.3 \\
\hline Sucrose equivalents ${ }^{y}$ & 427.5 & 113.4 \\
\hline \multicolumn{3}{|c|}{ Nonvolatile organic acids } \\
\hline Malic & 22.9 & 2.1 \\
\hline Citric & 0.9 & 0.9 \\
\hline Quinic & 3.4 & 4.0 \\
\hline $\begin{array}{l}\text { Total nonvolatile } \\
\text { organic acids }\end{array}$ & 27.2 & 7.0 \\
\hline
\end{tabular}

${ }^{2}$ Means for baked roots analyzed for sugars and organic acids by gas chromatography [HewlettPackard 5890A (Hewlett-Packard, Wilmington, Del.), flame ionization detector, DB-5 $0.25 \mu \mathrm{m}$ film thickness capillary column] of trimethylsilylated derivatives according to the method of Chapman and Horvat (1989).

${ }^{\mathrm{x}}$ Total reducing sugars $=$ glucose + fructose + maltose.

${ }^{y}$ Sucrose equivalents $=1.2$ (fructose content $)+1$ (sucrose) +0.64 (glucose) +0.43 (maltose) . 
Table 2. Relative concentrations $\left(\mu \mathrm{g} \cdot \mathrm{kg}^{-1} \mathrm{FW}\right)$ and flavor dilution (FD) factors ${ }^{\mathrm{z}}$ of the odor-active volatiles emanating from baked 'Jewel' and GA90-16 sweetpotatoes.

\begin{tabular}{|c|c|c|c|c|}
\hline \multirow[b]{2}{*}{ Volatile compound } & \multicolumn{2}{|c|}{ Jewel } & \multicolumn{2}{|c|}{ GA90-16 } \\
\hline & $\mu \mathrm{g} \cdot \mathrm{kg}^{-1}$ & $\overline{F D}$ & $\mu \mathrm{g} \cdot \mathrm{kg}^{-1}$ & FD \\
\hline Pyridine & 5.6 & 10 & 1.7 & 10 \\
\hline $1,2,4$-Trimethyl benzene & 2.7 & 800 & 2.0 & 400 \\
\hline 3-Furaldehyde & 14.5 & 10 & 2.4 & 10 \\
\hline Xylene & 0.3 & 1 & 0.1 & 1 \\
\hline 2-Furmethanol & 14.1 & 100 & 1.8 & 10 \\
\hline 2-Furancarboxaldehyde & 1.3 & 1 & 2.8 & 1 \\
\hline 2-Acetyl furan & 4.4 & 1000 & 2.8 & 1000 \\
\hline Benzaldehyde & 2.1 & 800 & 0.5 & 100 \\
\hline 5-Methyl-2-furfural & 0.9 & 400 & 0.7 & 400 \\
\hline 2-Pentyl furan & 1.2 & 1000 & 0.1 & 100 \\
\hline 2,3-Pentanedione & 0.7 & 10 & 1.5 & 10 \\
\hline Phenylacetaldehyde & 29.7 & 1500 & 20.9 & 800 \\
\hline Limonene & $\operatorname{tr}^{\mathrm{y}}$ & 10 & $\operatorname{tr}$ & 10 \\
\hline 3,4-Dihydropyran & 2.1 & 1 & 1.0 & 1 \\
\hline 2-Acetyl pyrrole & 0.3 & 1000 & 0.1 & 100 \\
\hline Maltol & 30.8 & 1500 & 0.7 & 1 \\
\hline Linalool & 0.8 & 800 & 0.2 & 100 \\
\hline Isopulegone & 0.8 & 100 & 0.2 & 10 \\
\hline Geraniol & 0.4 & 1000 & 0.1 & 100 \\
\hline 2,4-Nonadienal & 1.2 & 400 & $\operatorname{tr}$ & 10 \\
\hline Cyclohexanol & 5.4 & 1 & $\operatorname{tr}$ & 1 \\
\hline n-Decanal & $\operatorname{tr}$ & 100 & $\operatorname{tr}$ & 100 \\
\hline 2,2-Dimethyl-1,3-cyclohexanediol & 0.4 & 1 & 0.2 & 1 \\
\hline 2,3-Nonadecanediol & 0.5 & 10 & 2.5 & 100 \\
\hline 2,4-Decadienal & 0.6 & 400 & 1.9 & 1000 \\
\hline Octyl ketone & $\operatorname{tr}$ & 100 & 0.3 & 800 \\
\hline Methyl geranate & $\operatorname{tr}$ & 1500 & $\operatorname{tr}$ & 1000 \\
\hline Cyperene & $--^{x}$ & & 1.8 & 100 \\
\hline$\beta$-Farnesene & 0.3 & 10 & 0.3 & 10 \\
\hline$\alpha$-Copaene & 0.3 & 800 & 0.2 & 800 \\
\hline$\alpha$-Biszbolene & 0.3 & 10 & 0.2 & 10 \\
\hline Bohlmann 176 & 1.5 & 1 & 0.3 & 1 \\
\hline 2(4H)-Benzofuranone & 1.3 & 1 & 0.3 & 1 \\
\hline Sesquiterpene (MW 204) & --- & & 0.1 & 10 \\
\hline$\beta$-Ionone & 1.6 & 1000 & 0.8 & 400 \\
\hline Nerolidol & 0.2 & 10 & 0.1 & 10 \\
\hline 4-Decanolide & $\operatorname{tr}$ & 100 & $\operatorname{tr}$ & 100 \\
\hline Unknown 2 & 1.0 & 100 & 0.2 & 10 \\
\hline Tetradecanoic acid & 4.2 & 1 & 0.5 & 1 \\
\hline
\end{tabular}

${ }^{\mathrm{z}} \mathrm{FD}=$ flavor dilution factor determined by aroma extract dilution analysis (Wang and Kays, 2000). ${ }^{y} \operatorname{tr}=<1.0 \%$ of the volatile fraction, based on area of GC peak.

$\mathrm{x}_{---}=$Not detected. sweet and caramel odors in 'Jewel' from 2pentyl furan, 2-acetyl pyrrole, maltol, linalool, and geraniol tended to mask the baked potato aroma.

When prepared as french fries, GA90-16 absorbed less fat $(6.9 \%)$ than did 'Jewel' $(10.6 \%)$ and had a distinctly better appearance and texture. GA90-16 french fries were described by sensory panelists as yellowish and dry tasting, devoid of the typical sweetpotato flavor, while french fries from 'Jewel' were very dark, oily, and soft in texture.

The primary reasons for the pronounced flavor difference between GA90-16 and conventional North American cultivars are: 1) the low level of endogenous sugars (Table 1); 2) genes that confer low amylase synthesis; and 3 ) the general lack of carotene synthesis. Unlike traditional North American sweetpotatoes which contain $\beta$-carotene in the $60-90$ $\mu \mathrm{g} \cdot \mathrm{g}^{-1} \mathrm{DW}$ range (10-15 retinol equivalents/g DW) (Simonne et al., 1993), GA90-16 has negligible levels. This is important in that the carotenes and intermediates in the carotenoid synthesis pathway have a significant impact on flavor quality and intensity. While low carotene content is beneficial with regard to the flavor of staple-type cultivars, GA90-16 is a poor source of provitamin A. The degree to which $\beta$-carotene synthesis can be increased without an unacceptable impact on flavor will no doubt vary among consumer groups (Simonne et al., 1993).

Disease and insect resistance. The storage roots of GA90-16 have high resistance to injury from the elongate flea beetle and the pale striped flea beetle (Table 3). The line was grown for 8 years in Athens, Ga., and for 5 years in Charleston, S.C. During one season (Charleston), the roots appear to display stress cracking. GA90-16 displays very good resistance to southern root-knot nematode and high resistance to fusarium wilt (stem rot) (Table 3).

Yield. GA90-16 yields less than the most widely grown traditional North American

Table 3. Reaction of GA90-16 and other clones to southern root-knot nematode, flea beetle, and Fusarium wilt (stem rot) in tests at the U.S Vegetable Laboratory.

\begin{tabular}{|c|c|c|c|c|c|c|c|}
\hline \multirow[b]{2}{*}{ Clone } & \multicolumn{4}{|c|}{ Root-knot nematode } & \multirow[b]{2}{*}{ Fusarium DI $^{v}$} & \multirow[b]{2}{*}{ Ratingw } & \multirow[b]{2}{*}{ Flea beetle $\%^{\mathrm{u}}$} \\
\hline & Gall index ${ }^{z}$ & Egg mass index ${ }^{y}$ & Necrosis inde ${ }^{x}$ & Rating $^{\mathrm{w}}$ & & & \\
\hline GA90-16 & 1.0 & 1.0 & 1.3 & $\mathrm{HR}$ & $2.2 \mathrm{a}^{\mathrm{t}}$ & $\mathrm{HR}$ & $1.6 \mathrm{a}^{\mathrm{t}}$ \\
\hline Jewel & 2.2 & 2.1 & 1.3 & $\mathrm{R}$ & $2.2 \mathrm{a}$ & HR & $4.2 \mathrm{ab}$ \\
\hline Beauregard & 4.7 & 4.6 & 1.6 & $\mathrm{~S}$ & $2.2 \mathrm{a}$ & HR & $4.8 \mathrm{ab}$ \\
\hline Nemagold & 1.1 & 1.1 & 1.2 & HR & $4.9 \mathrm{c}$ & $\mathrm{S}$ & \\
\hline Porto Rico & 2.9 & 2.9 & 1.4 & $\mathrm{I}-\mathrm{S}$ & $4.5 \mathrm{~b}$ & $S$ & \\
\hline Regal & & & & & & & $2.0 \mathrm{a}$ \\
\hline SC1149-19 & & & & & & & $38.0 \mathrm{c}$ \\
\hline $\operatorname{LSD}_{0.05}{ }^{\mathrm{t}}$ & 0.8 & 0.8 & 0.3 & --- & 0.3 & --- & 2.01 \\
\hline
\end{tabular}

${ }^{2}$ Clones were planted in sand benches and inoculated with $\approx 3000$ eggs/plant of M. incognita Race 3 on 22 July 1997 and rated for galling and egg mass production on 24 Sept. 1997. Gall index: $1=$ no galling; $5=>80 \%$ of the root system galled.

${ }^{y}$ Egg mass index: $1=$ no egg masses; $5=>80 \%$ of root system covered with egg masses.

${ }^{x}$ Necrosis index: 1 = no necrosis; $5=$ severe necrosis.

"Rating: HR = highly resistant; $\mathrm{R}=$ resistant; $\mathrm{I}=$ intermediate; $\mathrm{S}=$ susceptible. Check clones: Nemagold $=\mathrm{HR}$; Jewel = R; Porto Rico = $\mathrm{I}-\mathrm{S} ;$ Beauregard $=\mathrm{S}$.

"The bottom $2.5 \mathrm{~cm}$ of freshly cut stems from sweetpotato clones were dipped in suspensions (150,000 conidia/ml) of Fusarium oxysporum f. sp. batatas conidia for $60 \mathrm{~s}$, planted in sand benches on 12 Sept. 1997, and rated for vascular discoloration for disease index on 26 Sept. 1997. Disease Index (DI): 1 = no symptoms; 2 = vascular infection only in callus; 3 = vascular infection up to first node; $4=$ extensive lesions, vascular infection above the first node, or both; $5=$ dead plant. Check clones: Jewel and Beauregard $=$ HR; Nemagold and Porto Rico $=\mathrm{S}$. uPercentage of roots with flea beetle damage. Values are means of four replications. Check clones: Regal = HR; SC1149-19= S.

'Mean separation within columns by Fisher's unprotected LSD test, $P \leq 0.05$. 
cultivars (e.g., 'Beauregard' and 'Jewel'). In Athens, total yields are generally $\approx 70 \%$ to $80 \%$ of 'Jewel', varying with year and location. Like other sweetpotato lines, yield could potentially be increased with specific horticultural techniques.

\section{Availability}

Rooted propagation material of GA90-16 is available from the Dept. of Horticulture or virus-indexed cultures from the USDA Plant Genetic Resource Conservation Unit, Griffin, Ga.

\section{Literature Cited}

Buttery, R.G., D.G. Guadagni, and L.C. Ling. 1973. Volatile components of baked potatoes. J. Agr. Food Chem. 24:1125-1131.

Chapman, G.W., Jr. and R.J. Horvat. 1989. Determination of nonvolatile acids and sugars from fruits and sweet potato extracts by capillary GLC and GLC/MS. J. Agr. Food Chem. 37:947-950.

Hamilton, M.G., P.D. Dukes, A. Jones, and J.M. Schalk. 1985. 'HiDry' sweet potato. HortScience 20:954-955.

Kays, S.J., Y. Wang, and W.J. McLaurin. 1999. Development of alternative flavor types of root and tuber crops as a means of expanding consumption. Trop. Agr. 75:271-275.
Royal Horticultural Society. 1987. Royal Horticultural Society Colour Chart. Royal Hort. Soc., London.

Simonne, A.H., S.J. Kays, P.E. Koehler, and R.R. Eitenmiller. 1993. Assessment of $\beta$-carotene content in sweetpotato breeding lines in relation to dietary requirements. J. Food Comp. Analysis 6:336-345.

Somda, Z.C. and S.J. Kays. 1990. Sweet potato canopy architecture: Branching pattern. J. Amer. Soc. Hort. Sci. 115:33-38.

Wang, Y. and S.J. Kays. 2000. Contribution of volatile compounds to the characteristic aroma of baked 'Jewel' sweetpotatoes. J. Amer. Soc. Hort. Sci. 125:638-643. 